\title{
Evidence for Large-Scale Astrocyte Death in the Developing Cerebellum
}

\author{
Bruce K. Krueger, Julia F. Burne, ${ }^{a}$ and Martin C. Raff ${ }^{a}$ \\ Medical Research Council Developmental Neurobiology Programme, Department of Biology, University College \\ London, London WC1E 6BT, United Kingdom
}

\begin{abstract}
There is increasing evidence that some glial cells die during normal vertebrate development, but the extent of the death and the types of glial cells that die remain uncertain. We have analyzed pyknotic cells in the developing postnatal rat cerebellum. During the first postnatal week, the majority of pyknotic cells are in the developing white matter where their number peaks at about postnatal day 7 (P7) and then declines sharply. Pyknotic cells in the internal granule cell layer peak at P10, while those in the molecular and external granule cell layers peak later. Both electron microscopy and in situ end labeling of DNA catalyzed by terminal deoxynucleotidyl transferase confirm that the pyknotic cells are undergoing apoptosis. Immunohistochemical staining suggests that $\mathbf{5 0 - 7 0 \%}$ of the pyknotic cells in the white matter and internal granule cell layer are astrocytes. We estimate that at P7, as many as $50 \%$ of the white matter cells die and, of these, more than half appear to be astrocytes.
\end{abstract}

[Key words: apoptosis, astrocyte, cerebellum, confocal microscopy, development, electron microscopy, fluorescence microscopy, glial fibrillary acidic protein, granule cell, oligodendrocyte, programmed cell death, pyknosis, S100, white matter]

It is now generally accepted that large-scale neuronal death is a regular feature of the development of the vertebrate nervous system (Cowan et al., 1984; Oppenheim, 1991; Johnson and Deckwerth, 1993). Much less attention has been given, however, to glial cell death (Hildebrand, 1971; Sturrock, 1976; Korr, 1980; Knapp et al., 1986). Barres et al. (1992) recently showed that about $50 \%$ of newly formed oligodendrocytes normally die in the developing rat optic nerve, suggesting that naturally occurring glial death can be just as substantial as naturally occurring neuronal death. In contrast to the large amount of oligodendro-

\footnotetext{
Received July 13, 1994; revised Nov. 28, 1994; accepted Dec. 5, 1994.

We are grateful to B. Friedman for anti-CNP (RIP) antibody and L. Old for anti-GD3 (R24) antihody. We thank B. A. Barres and J. T. Voyvodic for advice and helpful discussions; $C$. Hopkins and $M$. Shipman for assistance with confocal microscopy and image analysis; R. M. Meszler. M. Shagogue, E. B. Wade and J. B. Wade for assistance with electron microscopy; and B. A. Barres, H. Mudhar, and J. T. Voyvodic for comments on the manuscript. B.K.K. was the recipient of a Fogarty Senior International Fellowship from the NIH and a John Simon Guggenheim Memorial Fellowship. This work was supported, in part, by NIH Grant AG10686 to B.K.K.

Correspondence should be addressed to Bruce K. Krucger, Department of Physiology, University of Maryland School of Medicine, 660) West Redwood Street, Baltimore, MD 21201.

Present address: MRC Laboratory for Molecular Cell Biology, University College London, Gower Street, London WC1E 6BT, United Kingdom.

Copyright 1995 Society for Neuroscience (270-6474/95/153366-09\$05.00/0
}

cyte death, no astrocyte death was found in the developing postnatal rat optic nerve. It is unclear, however, how representative the optic nerve is of other developing regions in the CNS. Soriano et al. (1993), for example, reported that many of the dying cells in the postnatal rat cortex are astrocytes. In the prescnt study, we have quantitatively analyzed cell death during the development of the cerebellum which, unlike the optic nerve, contains neurons as well as glial cells.

The complex involution and stratification of the cerebellum are the consequences of extensive neurogenesis and gliogenesis and massive cell migrations, which occur postnatally in rodents and humans (Miale and Sidman, 1961; Altman, 1972a,b). In neonatal rats, the primitive cerebellum is composed primarily of Purkinje cells, neurons of the deep cerebellar nuclei, immature glial cells, and the neuronal precursor cells that form the external granular layer (EGL). Extensive proliferation in the EGL during the first 3 postnatal weeks gives rise to more than $10^{8}$ granule cells, which migrate inward past the Purkinje cells, to their final positions in the internal granule cell layer (IGL). During the same period, extensive invagination of the pial surface creates the cerebellar folia. At the core of these folia are the afferent climbing and mossy fibers and the efferent Purkinje cell axons. Initially, these axons are unmyelinated and are surrounded by astrocytes. During the first two postnatal weeks, however, proliferating oligodendrocyte precursors migrate into the cerebellum, via the superior medullary vellum, from germinal zones outside the cerebellum (Reynolds and Wilkin, 1988). These precursors differentiate into oligodendrocytes, which myelinate the axons.

The stereotyped structure of the cerebellum and the wealth of information about its development make it an attractive place to study normal cell death in the developing brain. Although cell death has been observed in developing cerebellum previously (Altman and Nicholson, 1971; Lewis, 1975; Koppel et al., 1983; Janowsky and Finlay, 1983; Smeyne and Goldowitz, 1989; Ashwell; 1990; Wood et al., 1993), the types of cells that die have not been established. The focus of this article will be the first 10 postnatal days, when most of the cell death in the cerebellum is occurring in the developing white matter and IGL and most of the dead cells are associated with immunoreactivity for the specific astrocyte markers, glial fibrillary acidic protein (GFAP) and S100. Cell death in the molecular and external granule layers, which occurs later in postnatal development, may be due to the death of future granule cell neurons and will be the subject of a separate communication.

\section{Materials and Methods}

Tissue preparation. Sprague-Dawley rats were bred in the UCL animal facility. The day of birth was designated postnatal day $0(\mathrm{P} 0)$. Rats of 
various ages from P3 to P14 were deeply anesthetized with pentobarbitone sodium and perfused transcardially with phosphate-buffered saline (PBS) followed by $4 \%$ paraformaldehyde in $0.1 \mathrm{~m}$ phosphate buffer, $\mathrm{pH}$ 7.4. Brains were postfixed in $4 \%$ paraformaldehyde overnight at $4{ }^{\circ} \mathrm{C}$ and cryoprotected with $30 \%$ sucrose in PBS. Frozen sections $(8 \mu \mathrm{m})$ were cut midsagittally through the vermis, applied to gelatinized slides, air dried, and then treated for $15 \mathrm{~min}$ in $70 \%$ ethanol at $-20^{\circ} \mathrm{C}$. The last step was omitted for sections stained with anti-GD3 or anti-CNP antibodies (see below).

Staining with propidium iodide and antibodies. Sections were incubated for $1 \mathrm{hr}$ at room temperature with 50\% sheep serum in PBS (for staining with nouse monoclonal antibodies) or $50 \%$ goat serum (for rabbit antisera). Astrocytes were visualized with rabbit antisera against either GFAP (Dako, diluted 1:100) or S100 (Sigma; 1:300). Cells of the oligodendrocyte lineage were visualized with monoclonal antibodies against either cyclic nucleotide phosphodiesterase (CNP, anti-RIP, 1:1; Friedman et al., 1989) or GD3 ganglioside (R24; 1:100; Goldman et al., 1984). All dilutions were in $145 \mathrm{~mm} \mathrm{NaCl}, 50 \mathrm{~mm}$ Tris, $100 \mathrm{~mm}$ lysine, $10 \mathrm{mg} / \mathrm{ml}$ bovine serum albumin, $0.4 \mathrm{mg} / \mathrm{ml}$ sodium azide, $\mathrm{pH}$ 7.4 (TBLS), and incubations were for $1 \mathrm{hr}$ at room temperature. Secondary antibodies were biotinylated donkey anti-rabbit Ig or biotinylated sheep anti-mouse IgG followed by fluorescein-coupled streptavidin (all from Amersham; 1:100) in TBLS and applied for 30 min at room temperature. Nonspecific staining, determined by omitting the primary antibody, was negligible. Finally, in order to stain cell nuclei and identify apoptotic cells, all sections were incubated with $5 \mu \mathrm{g} / \mathrm{ml}$ propidium iodide (PI) and $0.1 \mathrm{mg} / \mathrm{ml}$ RNase (DNase-free) in PBS for 15 min at $37^{\circ} \mathrm{C}$ (Barres et al.. 1992). Slides were examined in Zeiss Universal or Olympus fluorescence microscopes $(25 \times, 0.8$ n.a., $40 \times, 1.0$ n.a., or $100 \times 1.4 \mathrm{n}$.a. oil immersion objectives), using a fluorescein filter set for fluorescein and Texas red or rhodamine filter sets for PI. Color photographs were taken with Kodak Ektar 1000 film and black and white photographs were taken with Kodak Tri-X or TMAX 400 film. In some cases sections were examined in a Bio-Rad MRC600 fluorescence scanning confocal microscope equipped with an argonkrypton laser. Images were obtained by photographing the computer display using Kodak Ektar $100 \mathrm{film}$.

Cell counting. PI-labeled normal cerebellar nuclear profiles are generally oval in shape, approximately $5 \times 7 \mu \mathrm{m}$ in size, and have a slight granular appearance. In contrast, PI-stained apoptotic nuclei are compact, bright red-orange spheres, $1-4 \mu \mathrm{m}$ in diameter and are frequently fragmented, appearing as clusters of two or more bright spheres (two or more such particles within $5 \mu \mathrm{m}$ of one another were counted as one apoptotic cell). Using phase contrast optics, apoptotic cells appear much darker than normal or mitotic cells. For each age, at least two, nonserial, $8 \mu \mathrm{m}$ midsagittal sections through the cerebellum were analyzed from each of three or more animals. All sections were located near the midline and excluded deep cerebellar nuclei. In each section, apoptotic cells were counted by PI fluorescence or phase contrast in all 10 lobes (Larsell, 1952) in each of four cerebellar layers-the EGL, the molecular layer (ML), the internal granule cell-Purkinje cell layer (IGL), and the developing white matter (WM). There were no significant differences in the density of apoptotic cells among the lobes. Prior to P7, there is no clear demarcation between the future WM and the IGL, however, at P3 and P5, this junction was operationally defined as the point at which the granule cell nuclear density decreased noticeably and a dense network of $\mathrm{GFAP}^{+}$processes began.

The area of each of the cerebellar layers (EGL, ML, IGL, WM) was estimated as follows: representative midsagittal sections at each age were Nissl-stained $(0.1 \%$ cresyl violet, $10 \mathrm{~min})$ and images were digitized using a CC.D viden camera. The area of each layer was determined using a Macintosh-based image processing system (Adobe PHOTOSHOP).

An estimate of the percentage of apoptotic cells in the WM was made at P7. In order to correct for overestimates of particle counts from profile counts (Cruz-Orive and Weibel, 1990; Coggeshall, 1992), apoptotic nuclei were counted in serial midsagittal sections. Approximately $12 \%$ of the apoptotic nuclei appeared in the adjacent serial section and the apoptotic index was corrected for this factor. In order to reduce errors due to normal nuclei spanning two or more sections, counts of PIstained nuclei in three representative regions of the P7 WM were determined by the "optical disector" method (Cruz-Orive and Weibel, 1990; Bertram and Nurcombe, 1992) using the confocal microscope to optically section in $0.5 \mu \mathrm{m}$ steps. Normal nuclei were counted in a 146 $\times 96 \mu \mathrm{m}$ area across the middle $75 \%$ of each section. Nuclei were not counted when their topmost part appeared outside this central zone. The apoptotic index was calculated as follows:

apoptotic index $=\frac{\text { corrected number of apoptotic nuclei } / \mu \mathrm{m}^{2}}{\text { number of normal nuclei } / \mu \mathrm{m}^{2}} \times 100 \%$

Electron microscopy. $\mathrm{P} 7$ rats were perfused with $4 \%$ paraformaldehyde in $0.1 \mathrm{M}$ phosphate buffer, $\mathrm{pH}$ 7.2. One millimeter, midsagittal cerebellar slices were cut with a razor blade and immersed in buffer containing $3 \%$ glutaraldehyde. After fixing overnight at $4^{\circ} \mathrm{C}$, the tissue was washed and postfixed in $1 \%$ osmium tetroxide for $2 \mathrm{hr}$ at $4^{\circ} \mathrm{C}$, stained "en bloc" with uranyl acetate, dehydrated in a series of alcohols, and embedded in EPON. Thin sections were cut on an LKB ultramicrotome, counterstained with lead citrate and uranyl acetate, and examined using a JEOL $100-\mathrm{CX}$ II electron microscope at $80 \mathrm{kV}$.

In situ terminal deoxynucleotidyl transferase (TdT) labeling of fragmented DNA. Labeling was carried out on $8 \mu \mathrm{m}$ frozen sections of P7 rat cerebellum, prepared as described above, by a modification of the methods of Gavrieli et al. (1992) and Wijsman et al. (1993). Sections were postfixed in $70 \%$ ethanol for $20 \mathrm{~min}$ at $-20^{\circ} \mathrm{C}$ and treated with $0.26 \mathrm{U} / \mu \mathrm{l}$ TdT (U.S. Biochemicals), $20 \mu \mathrm{M}$ biotinylated-14-dUTP (Boehringer Mannheim), $100 \mathrm{~mm}$ K-cacodylate, $1 \mathrm{mM} \mathrm{CoCl}_{2}, 0.5 \mathrm{~mm}$ dithiothreitol, pH 7.2 for $60 \mathrm{~min}$ at $37^{\circ} \mathrm{C}$. Sections were then washed three times with PBS and then treated with $2 \%$ BSA in PBS for $20 \mathrm{~min}$ at room temperature. Finally, the sections were treated with fluoresceincoupled streptavidin $(1: 100)$ in PBS for $30 \mathrm{~min}$, mounted in Citifluor. and viewed under rhodamine (PI) or fluorescein (end-labeling) optics. Sections were photographed using Kodak, TMAX-400 film.

\section{Results}

Cell death in the developing cerebellum. Pyknotic cells were observed in all four cortical layers of the cerebellum from P3 to Pl4 (Figs. 1, 2). These cells appeared dark with phase contrast optics and, when stained with propidium iodide $(\mathrm{PI})$, were seen to have bright, spherical nuclei, $1-4 \mu \mathrm{m}$ in diameter. Figure $2 A$ shows the total numbers of pyknotic cells in each area in sections containing all 10 lobes of the cerebellum. During the first postnatal week, the majority of these cells were in the developing white matter (WM) and, to a lesser extent, in the IGL; there were very few in the EGL or the developing molecular layer (ML). The numbers of pyknotic cells peaked in the WM at P7 and in the IGL at P10, and dying cells had nearly disappeared from both regions by $\mathrm{P} 14$. The number of pyknotic cells in the EGL and ML increased during the second postnatal week and had not yet started to decrease by P14.

We also calculated the density of pyknotic cells in each layer by dividing the total number of pyknotic cells per section in each cerebellar layer by the total area of that layer (see Materials and Methods). As is evident in Figure $2 B$, the density of pyknotic cells (number $/ 10^{6} \mu \mathrm{m}^{2}$ ) during the first postnatal week was greatest in the WM, whereas the density during the second week was greatest in the EGL. The density of pyknotic cells in the IGL and ML, which grow rapidly during this period, was low throughout both wccks.

Identification of apoptotic cells by their condensed (pyknotic) nucleus has been used extensively to quantitate cell death in the nervous system. The identification is sometimes ambiguous, however, and it is possible that structures other than apoptotic nuclei (e.g., nuclei of embryonic rodent erythrocytes (Coggeshall et al., 1993) could be counted. A common feature of apoptosis is the degradation of the nuclear DNA into oligonucleosome-sized fragments (Arends et al., 1990). DNA fragmentation can be detected in individual cells in situ by incubating tissue sections with biotinylated dUTP in the presence of terminal deoxynucleotidyl transferase (TdT), which adds multiple biotinylated dUTP residues to the $3^{\prime}$ ends of DNA fragments (Gavrieli et al., 1992; Gorczyca et al., 1993; Wijsman et al., 1993). 

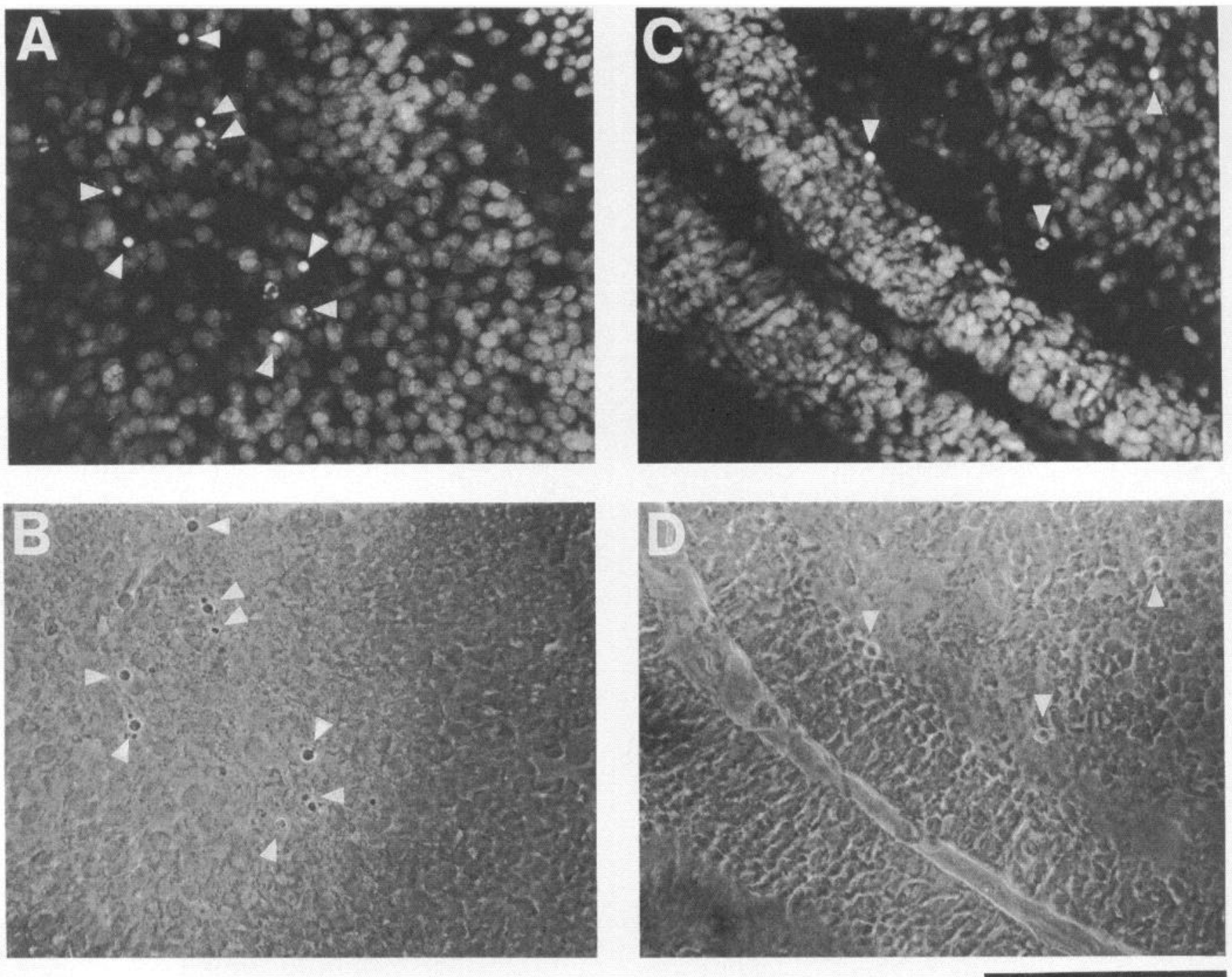

Figure 1. Postnatal rat cerebellum stained with PI and photographed with Texas red fluorescence optics $(A, C)$ or phase contrast optics $(B, D)$ to show normal and apoptotic (arrows) nuclei. $A$ and $B$ : P7, lobe VIa, apoptotic nuclei in WM; $C$ and $D$ : P10, lobe V, apoptotic nuclei in EGL, ML, and IGL. Apoptotic nuclei are prevalent in the developing WM tracts up to P7 but are rare after P10. Scale bar, $100 \mu \mathrm{m}$.

Figure 2. A, Number of apoptotic nuclei in each of the four cerebellar layers at various postnatal ages. Data represent the number of apoptotic nuclei observed in all 10 lobes per $8 \mu \mathrm{m}$ midsagittal section. $B$, Same data as in $A$ normalized for the area of layer (see Materials and Methods). Error bars indicate SEM.
A

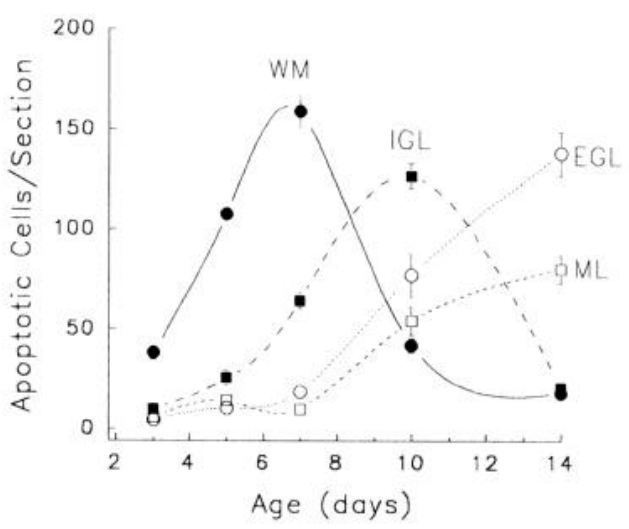

B

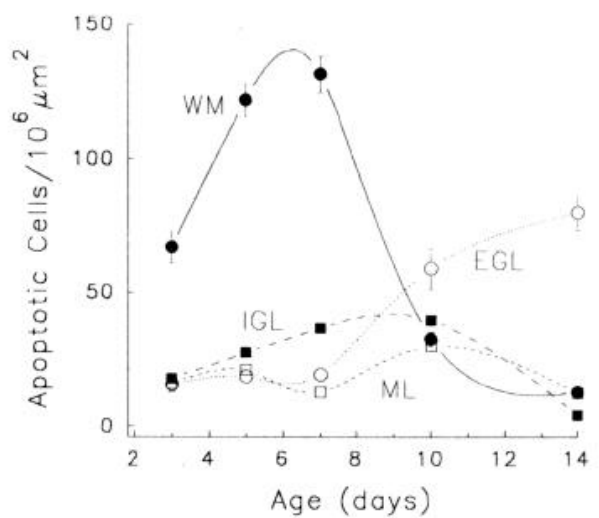



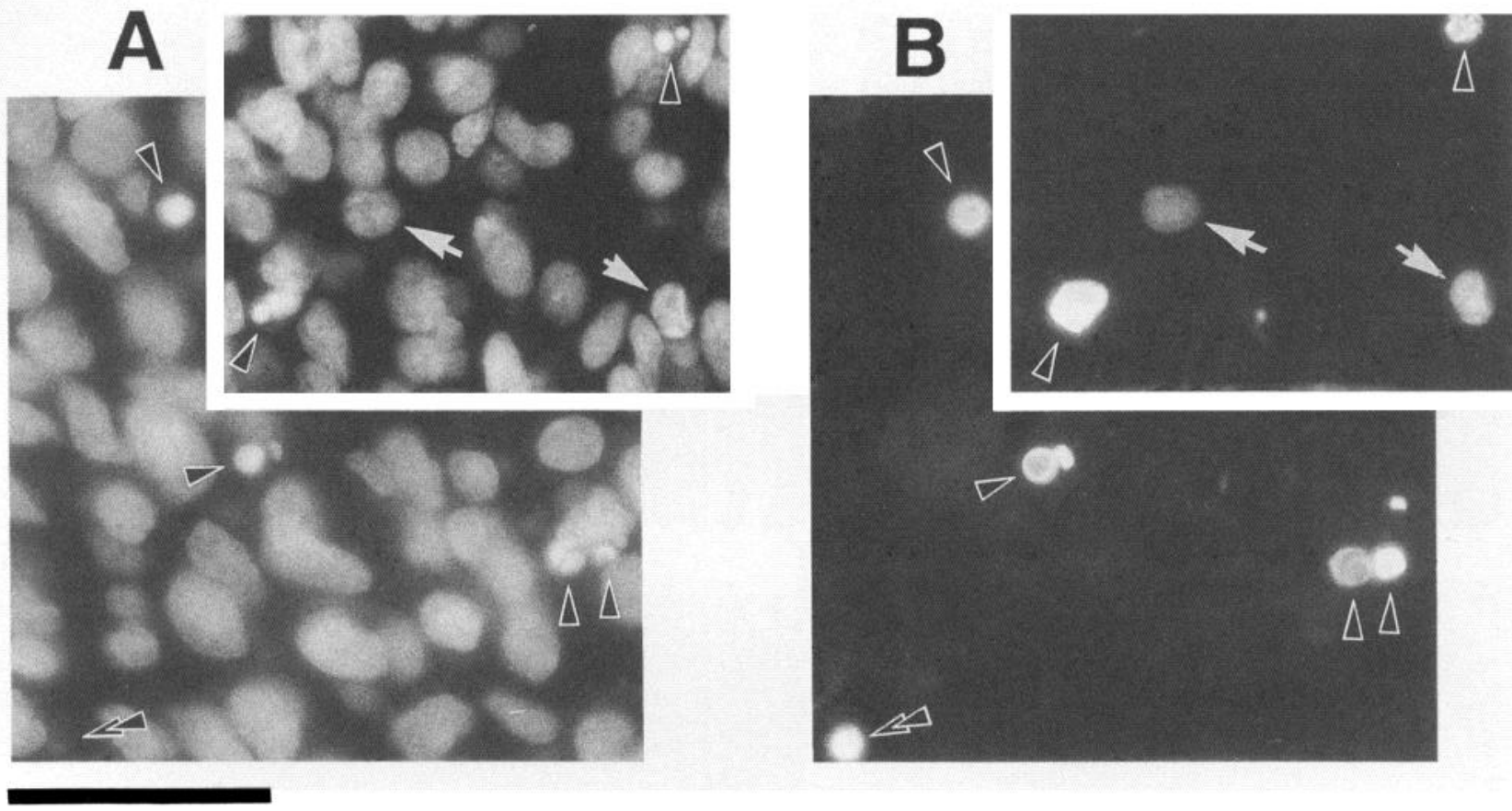

Figure 3. TdT-catalyzed in situ end-labeling of fragmented DNA in frozen sections of P7 rat cerebellum. The sections were labeled with biotinylated dUTP using TdT and counterstained with PI as described in Materials and Methods. Incorporation of dUTP onto free 3' ends of DNA fragments was detected using fluorescein-coupled streptavidin. A, Two fields from P7 cerebellar WM viewed with rhodamine optics to reveal PIstained pyknotic nuclei. $B$, Same fields viewed with fluorescein optics to reveal dUTP incorporation (DNA fragmentation). The arrowheads point to PI-labeled pyknotic nuclei $(A)$ that are also undergoing DNA fragmentation $(B)$. Arrows (insets) point to TdT-labeled nuclei $(B)$ that do not appear to be pyknotic with PI labeling $(A)$. The double arrowheads indicate a nucleus that is TdT labeled $(B)$ that is not detectable with PI labeling (A). Scale bar, $20 \mu \mathrm{m}$.

Those nuclei containing many DNA fragments (and hence many free $3^{\prime}$ ends) can be detected by labeling with fluorescein-coupled streptavidin and viewing the cells in a fluorescence microscope. When sections of P7 rat cerebellum were TdT-end-labeled as described in Materials and Methods and counterstained with PI, many PI-stained pyknotic nuclei were observed in the WM and EGL (Fig. 3A); almost all $(>95 \%)$ of these were also fluorescein labeled (Fig. 3B) demonstrating that these pyknotic nuclei contained fragmented DNA. About $5 \%$ of the fluoresceinlabeled nuclei were not obviously pyknotic and may have been in the early phases of apoptosis (Fig. 3, arrows).

In order to obtain an indication of the fraction of the total number of cells that die in the WM, we determined the pyknotic index at P7, which is the point of maximal cell death in this layer (Fig. 2). Using the stereological methods described in Materials and Methods, we determined that there were $75 \pm 6$ PIstained nuclei in each $143 \times 96{\mu \mathrm{m}^{2}}^{2}$ area of WM analyzed, giving a density of normal cells of $5.5 \pm 0.4 \times 10^{-3} \mu \mathrm{m}^{2}$ in the P7 WM. Using the value of $1.14 \times 10^{-4}$ pyknotic cells per $\mu \mathrm{m}^{2}$ (from Fig. $2 B$, corrected as described in Materials and Methods), the pyknotic index calculated from Equation 1 was $2.1 \pm 0.2 \%$. Thus, $2 \%$ of the cells in the P7 WM were dead.

Identity of dead cells in WM and IGL. Because most of the death in the first postnatal week was in the WM, we focused our attention on glial cells. To identify the cell types undergoing apoptosis in the WM and IGL, cerebellar sections were doublelabeled with PI to identify the pyknotic cells and with antibodies to identify glial cells types: we used anti-GFAP or anti-S100 antibodies to identify astrocytes (Bignami et al., 1972; Boyes et al., 1986) and anti-GD3 or anti-CNP antibodies to identify cells of the oligodendrocyte lineage (Goldman et al., 1984; Reynolds and Wilkin, 1988; Friedman et al., 1989). Figure 4 shows examples of pyknotic cells that were judged to be astrocytes in conventional fluorescence micrographs of sections double-labeled with PI and either anti-GFAP or anti-S100 antibodies. Because it is sometimes difficult to tell whether the GFAP or $\mathrm{S} 100$ immunoreactivity associated with a nucleus is intrinsic to the cell or is instead associated with processes from neighboring cells, only pyknotic nuclei that were entirely surrounded by GFAP or S100 immunoreactivity were scored as $\mathrm{GFAP}^{+}$or $\mathrm{S} 100^{+}$

To check our assignments further, several pyknotic cells that were scored as $\mathrm{GFAP}^{+}$or $\mathrm{S} 100^{+}$by conventional fluorescence microscopy were examined by laser scanning confocal microscopy, which allowed us to reconstruct the PI and antibody fluorescence in three dimensions. Figure 5 shows a series of confocal images in $1 \mu \mathrm{m}$ increments through a pyknotic GFAP ${ }^{+}$ cell. It can be seen that the GFAP immunoreactivity completely surrounds the pyknotic nucleus in three dimensions, suggesting that the GFAP is intrinsic to the dying cell. Similar results were obtained with pyknotic cells labeled with anti-S100 antibodies (data not shown).

As summarized in Table 1, about $50 \%$ of the pyknotic cells in the WM and IGL were $\mathrm{GFAP}^{+}$, while $70 \%$ were $\mathrm{S} 100^{+}$, suggesting that the majority of dead cells were astrocytes. These percentages are minimum values, as only dead cells that were unequivocally labeled by the antibodies were counted as positive. By contrast, pyknotic cells in the ML and EGL were only rarely $\mathrm{GFAP}^{+}$or $\mathrm{S}_{100^{+}}(<1 \%)$. The number of $\mathrm{GFAP}^{+}$and $\mathrm{S} 00^{+}$pyknotic cells in the more mature core regions of the WM (at the proximal ends of the folia near the fourth ventricle) was similar to that in the less mature regions of the WM (at the 

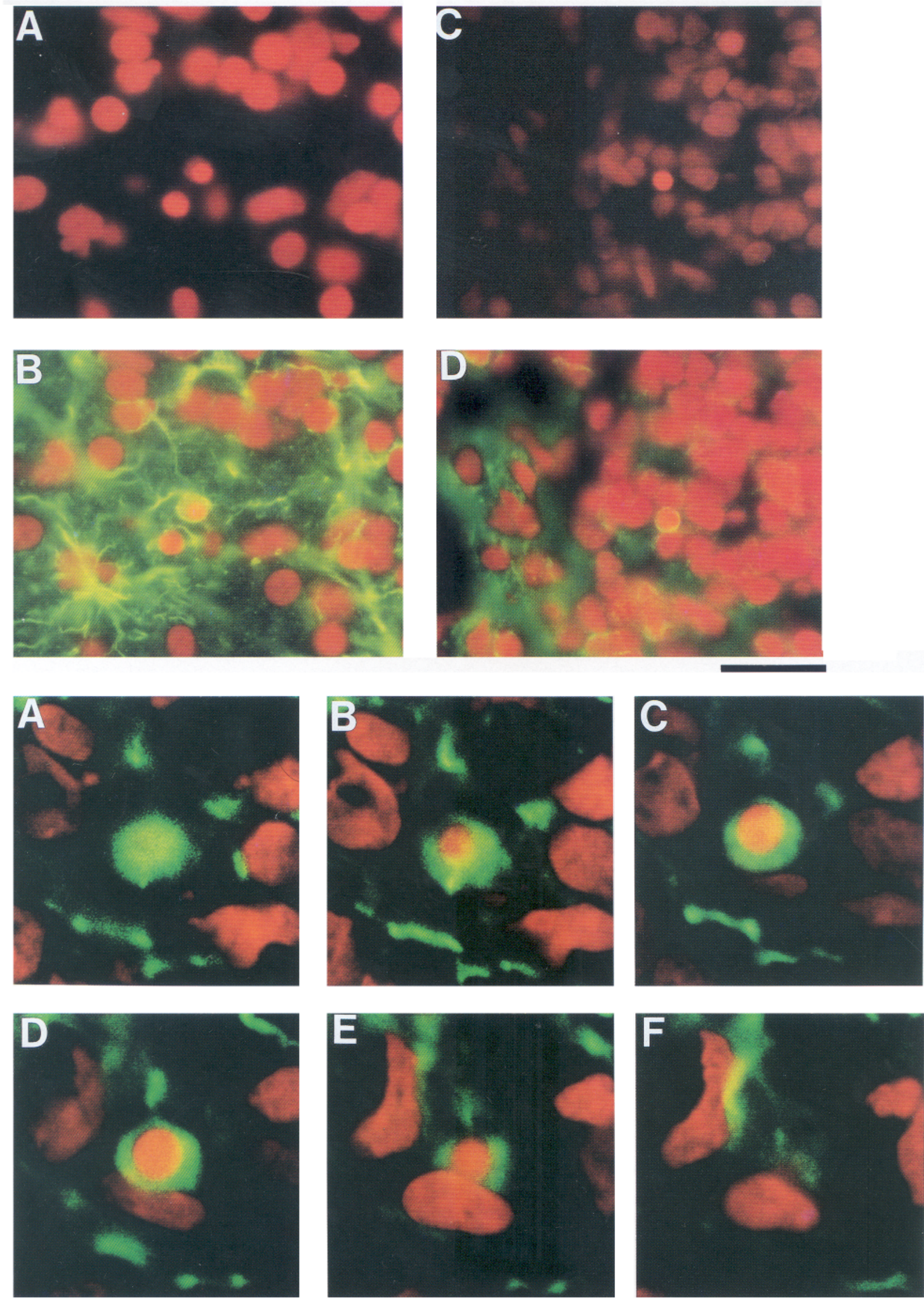
Table 1. Percentage of total apoptotic cells

\begin{tabular}{llllll} 
& \multicolumn{3}{l}{ GFAP $^{+}$} & & \multicolumn{2}{c}{ S100 $^{+}$} & \\
\cline { 2 - 3 } & WM & IGL & WM & IGL \\
\hline P3 & 48 & 19 & 66 & 18 \\
P7 & 54 & 41 & 71 & 70 \\
P10 & 58 & 41 & 69 & 70 \\
P14 & 44 & 38 & ND & ND
\end{tabular}

Midsagittal sections of P3-P14 rat cerebellum were stained with PI and either anti-GFAP or anti-S 100 antibodies. Total GFAP or $\mathrm{S} 100^{\circ}$ pyknotic nuclei were counted in each cerebellar layer throughout all 10 lobes. Results are expressed as percentage of GFAP or percentage of S100' pyknotic cells in the WM and IGL and represent the means of counts from at least two sections from each of two animals at each age. As only cells that were unambiguously labeled by the antibodies were scored as positive, these figures represent minimum values. An unambiguous assignment was more difficult for GFAP than for $\mathrm{S} 100$, which might account, at least in part, for the discrepancy between the percentages of GFAP' and $\mathrm{S} 100^{\prime}$ apoptotic cells. ND, Not determined.

peripheral ends of the folia). The fraction of dead cells that were

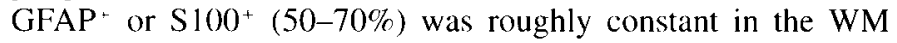
and IGL from P3 to P14 (Table 1). About $2 \%$ of the pyknotic cells in the WM and IGL were labeled with antibodies to the oligodendrocyte lineage markers, GD3 or CNP, at any age up to Pl4 (data not shown). None of the pyknotic cells in the ML or EGL were $\mathrm{GD}^{+}$or $\mathrm{CNP}^{\prime}$ and, as reported previously (Reynolds and Wilkin, 1988), no cerebellar cells were immunostained for both GD3 and GFAP.

Electron microscopy. To further characterize the dead cells in developing cerebellar WM, we examined P7 cerebellum by electron microscopy. The WM contained numerous cell profiles containing electron dense, condensed nuclei (Fig. 6). In almost all cases, the pyknotic cells were surrounded by healthy cytoplasm, suggesting that they had been phagocytosed by neighboring cells. In every case, the cytoplasm of the pyknotic cell was so disorganized that it was not possible to identify organelles such as glial filaments that might identify the nature of the dying cells. Intermediate filaments were rarely seen in the healthy cytoplasm surrounding the dead cells and, when there were such filaments, they were few and did not occur in bundles. It is not clear, however, whether glial filaments, identifiable by electron microscopy, are present in all astrocytes at this time in cerebellar development. Ashwell (1990) has reported that the number of microglia in the WM of the mouse cerebellum increases during the first postnatal week, peaking at about P7, and that some of these microglia contained pyknotic nuclei in their cytoplasm, suggesting that they were in the process of phagocytosing dead cells. Therefore, although the nature of the phagocytotic cells is uncertain, it seems likely that at least some of them were microglial cells.

\section{Discussion}

Although cell death has been known to be a fundamental feature of animal development for many years (Glucksmann, 1951;
Wyllie et al., 1980; Clarke, 1990; Ellis et al., 1991), its prevalence is still probably greatly underestimated. An important reason for this is that when cells die by apoptosis in normal development, they are rapidly phagocytosed and digested by their neighbors or by macrophages, without eliciting an inflammatory response, so that even large-scale cell death is usually histologically inconspicuous (Wyllie et al., 1980). Thus, while it is now widely recognized that up to $50 \%$ or more of many types of vertebrate neurons die during normal development, this massive death was missed by earlier investigators (Oppenheim, 1981, 1991; Jacobson, 1991). Only recently has it been recognized that about $50 \%$ of newly formed oligodendrocytes die during normal development, at least in the rat optic nerve (Barres et al., 1992). The present study was undertaken to determine the extent of cell death in the postnatal rat cerebellum during the period when there is considerable growth and differentiation of both neurons and glia, and to attempt to identify the cell types that are dying.

Apoptotic cell death in the developing cerebellum. The cell deaths in the developing cerebellum had the characteristics of apoptosis. In phase contrast microscopy, the dead cells appeared dark (Fig. 1) and, in fluorescence microscopy of PI-stained sections, the dead cell nuclei were condensed (Figs. 1, 3, 4). In electron microscopy of developing cerebellar white matter, where we focused our attention (Fig. 6), the dead cells had the characteristic ultrastructural features associated with apoptosis (Wyllie et al., 1980; Clarke, 1990). Moreover, when sections were subjected to TdT-catalyzed in situ end labeling of DNA (Gavrieli et al., 1992), virtually all of the nuclei identified as pyknotic by PI staining were also end-labeled (Fig. 3, arrowheads), suggesting that the dead cells contained fragmented DNA; an occasional nucleus that was not pyknotic by PI staining was end-labeled (Fig. 3, arrows, double arrowheads), suggesting that DNA fragmentation may begin before nuclear condensation (Arends et al., 1990).

Using PI fluorescence staining and phase contrast microscopy to identify apoptotic cells, we found that up to P10, most of the deaths occur in the developing WM and IGL, whereas later, most of the deaths occur in the EGL and ML (Fig. 2). Several previous studies have described cell death in the developing WM or IGL (Janowsky and Finlay, 1983; Ashwell, 1990; Wood et al., 1993) or in the EGL (Altman and Nicholson, 1971; Lewis, 1975; Koppel et al., 1983; Smeyne and Goldowitz, 1989), but no attempt was made to identify the types of cells that were dying.

Most of the dead cells in the early postnatal rat cerebellum appear to be astrocytes. In double-labeling experiments, using anti-GFAP or anti-SI00 antibodies to identify astrocytes, together with PI staining to identify dead cells, we found that $50-70 \%$ of the dead cells in the developing WM and IGL appeared double labeled, suggesting that most of the dead cells were astrocytes. Pyknotic GFAP ${ }^{+}$cells were also observed in postnatal rat cortex, although the total number of dying cells was not esti-

\section{$\leftarrow$}

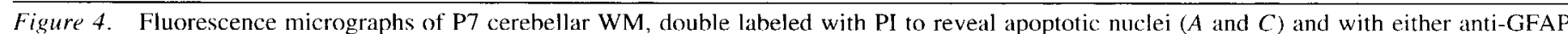

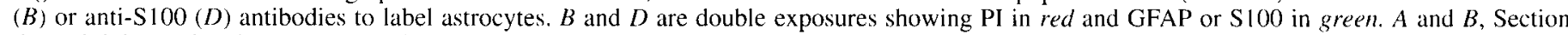

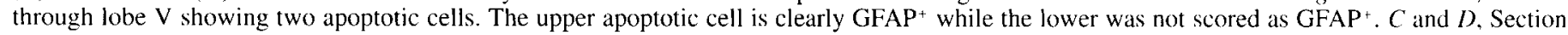
through lobe IV showing a single apoptotic cell that is $\mathrm{S} 100^{+}$. Scale bar, $25 \mu \mathrm{m}$.

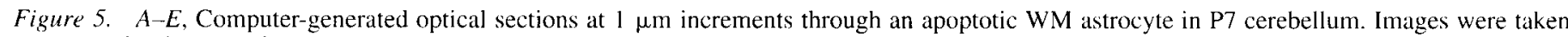

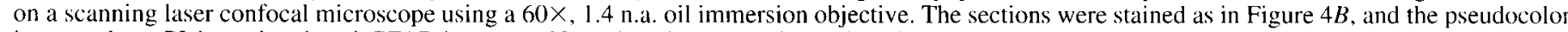

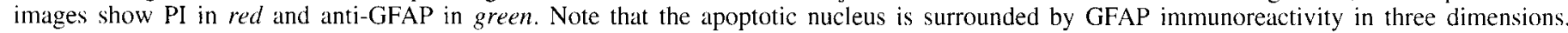
Scale bar, $10 \mu \mathrm{m}$. 

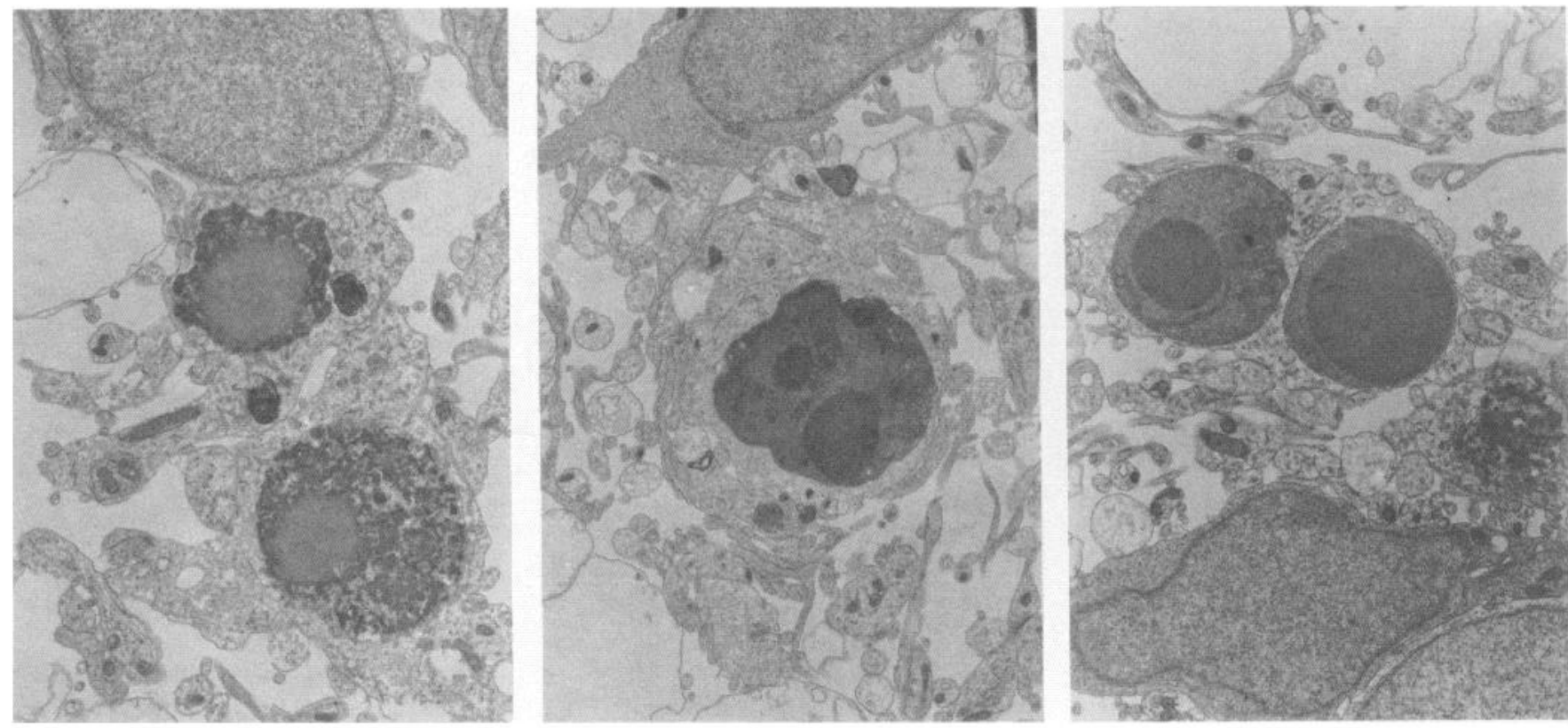

Figure 6. Electron micrographs of apoptotic cells in P7 WM. P7 rats were fixed by perfusion with $4 \%$ paraformaldehyde and $0.5 \%$ glutaraldehyde. Ultrathin sections were stained with lead citrate/uranyl acetate. Three representative fields in the WM are shown. The apoptotic cells are surrounded by apparently healthy cells. Scale bars, $4 \mu \mathrm{m}$.

mated (Soriano et al., 1993). In electron micrographs, most of these dead cells appeared to be inside the processes of healthy cells, suggesting that the dead cells had been phagocytosed. It was not possible from the ultrastructural features to identify the nature of either the dead cells or the phagocytic cells.

Is it possible that many, or even all, of the dead cells associated with GFAP or S100 immunoreactivity in the immunofluorescence studies were nonastrocytes that had been phagocytosed by astrocytes? Although we cannot exclude this possibility, we think it is unlikely for two reasons. First, microglial cells rather than astrocytes are thought to be mainly responsible for clearing cells that undergo normal cell death in the vertebrate CNS, at least in the postnatal rodent brain (Ashwell, 1990). The cells that phagocytose retinal ganglion cells undergoing normal cell death have the morphology and antigenic phenotype of microglial cells or macrophages (Hume et al., 1983; Perry et al., 1983). Moreover, when postnatal rat optic nerve is double labeled with PI and anti-GFAP antibodies, even though there is large-scale death of oligodendrocytes and there are a large numbers of $\mathrm{GFAP}^{+}$astrocytes present, no $\mathrm{GFAP}^{+}$pyknotic cells are seen (Barres et al., 1992). Second, when several pyknotic $\mathrm{GFAP}^{+}$cells and several $\mathrm{S} 100^{+}$cells in cerebellar WM were examined by scanning laser confocal microscopy to generate serial, $1 \mu \mathrm{M}$ thick, optical sections, the GFAP and S100 fluorescence was seen to completely surround the PI-stained pyknotic nucleus in three dimensions without any obvious intervening $\mathrm{GFAP}^{-}$or $\mathrm{S}_{100^{-}}$cytoplasm (see Fig. 5), suggesting that the GFAP and S100 staining were intrinsic to the dead cells. For these reasons, we suspect that most of the cells that die in the WM and IGL of the early developing cerebellum are astrocytes.

Based on their location in the cerebellar cortex, Wood et al. (1993) concluded that cells undergoing nuclear DNA fragmentation in the mouse IGL during the first 2 postnatal weeks were dying granule cells. No independent evidence of the identity of the dying cells was provided, however. Our results suggest that many of the cells may have been astrocytes.

It is not clear why astrocytes should die in the developing cerebellum but not in the developing optic nerve (at least postnatally in the rat; Barres et al., 1992). In principle, this difference could reflect intrinsic differences between cerebellar astrocytes and optic nerve astrocytes, environmental differences, or both.

How many cells die in the developing cerebellar white matter? We found that about $2 \%$ of the cells in the P7 cerebellar WM were apoptotic at any one time. Previous estimates for the apoptotic index in the brain range from about $0.25 \%$ to about 1\% (Sturrock, 1976; Koppel et al., 1983; Perry et al., 1983; Knapp et al., 1986; Gould et al., 1991; Barres et al., 1992). In order to determine the rate at which the cells die, one needs to know the rate at which dead cells are cleared to the point that they are no longer recognizable. Published estimates of clearance times for normal cell deaths vary from $10 \mathrm{hr}$ to less than an hour (Koppel et al., 1983; Bursch et al., 1990). In the developing rat optic nerve, for example, dead oligodendrocytes seem to be cleared in about an hour or less (Barres et al., 1992): even though at least 10,000 oligodendrocytes die each day, the total number of apoptotic nuclei seen in the nerve by PI staining at any one time is about 400 and the maximum apoptotic index is about $0.3 \%$. In the postnatal rat retina, dead ganglion cells are cleared in about $3 \mathrm{hr}$ : about 13,000 retinal ganglion cells die each day for the first few postnatal days, the total number of apoptotic cells seen in the retinal ganglion cell layer at any one time is about 1500 , and the apoptotic index is about $0.5 \%$ (Potts et al., 1982; Perry et al., 1983). If apoptotic cells are cleared within $1 \mathrm{hr}$ in the cerebellar WM, as they are in the optic nerve, then our finding that the apoptotic index at P7 is $2 \%$ suggests that $50 \%$ of the cells in the cerebellar WM die each day toward the end of the first postnatal week.

Our study deals only with astrocyte death. It is reasonable to 
expect, however, that some astrocytes are proliferating during this time (cf. Skoff and Knapp, 1991) and so it is not clear whether the total number of astrocytes in the WM increases, decreases or remains constant during the P3-P14 period. Previous studies have demonstrated that expression of GFAP (Bovolenta et al., 1984) and GFAP mRNA (Landry et al., 1990) peaks between $\mathrm{P} 7$ and P14 and then decreases substantially during the final period of cerebellar development. Our results suggest that at least some of this decrease in GFAP expression may be due to astrocyte death rather than to the downregulation of astrocyte GFAP.

Oligodendrocyte lineage cells also die in the developing cerebellum. About $2 \%$ of the apoptotic cells stained with the monoclonal anti-CNP or anti-GD3 antibodies that we used to identify cells of the oligodendrocyte lineage (Goldman et al., 1984; Reynolds and Wilkin, 1988; Friedman et al., 1989). These antibodies would only be expected to detect a minority of the cells in this lineage. In the rat optic nerve, for example, whereas about $90 \%$ of the dead cells were labeled on their surface with an oligodendrocyte-specific monoclonal anti-galactocerebroside (GC) antibody (when the hybridoma cells secreting the antibody were transplanted into the brain), only about $15 \%$ were labeled with the anti-CNP antibody (Barres et al., 1992). Moreover, GD3 is lost from oligodendrocytes soon after they differentiate (Goldman et al., 1984; Reynolds and Wilkin, 1988). Thus, we cannot accurately estimate from our results how much death normally occurs in the oligodendrocyte lineage in the developing cerebellum. It could be substantial as it is in the developing optic nerve, where the apoptotic index is $\leq 0.3 \%$ when $50 \%$ of the oligodendrocytes are dying each day. About $30 \%$ of the dead cells in the cerebellar WM did not stain detectably with any of the antibodies we used, and at least some of these could have been oligodendrocytes.

Why should astrocytes die? In the case of developing vertebrate neurons, it is widely believed that many of the cells normally die as a result of a competition for survival (neurotrophic) factors released by the target cells that the neurons innervate (Cowan et al., 1984; Oppenheim et al., 1988; Barde, 1989); only some of the neurons get enough factor to survive, while the others undergo apoptosis. This culling process is thought to play an important part in matching the numbers of presynaptic and postsynaptic cells, during both evolution (Purves, 1988) and development (Cowan et al., 1984). There is evidence that a similar competition for limiting amounts of survival factors may explain the normal oligodendrocyte deaths in the developing optic nerve (Barres et al., 1992), where the competition might serve to match the number of oligodendrocytes to the number and length of retinal ganglion cell axons requiring myelination (Barres et al., 1993). There may be a similar explanation for the apparent large-scale astrocyte death that occurs in the developing cerebellum. It is possible that cerebellar astrocytes, like neurons and oligodendrocytes, are overproduced and then eliminated as a mechanism to adjust their numbers to the needs of the tissue.

The timing of the astrocyte death may provide clues as to why it occurs. In the rat cerebellum at birth, postmitotic Purkinje cells are aligning below the newly arrived granule cell precursors of the EGL. The future WM tracts consist of as yet unmyelinated afferent (climbing and mossy fibers) and efferent (Purkinje cell axons) together with astrocytes and their precursors. At about this time, oligodendrocyte precursor cells begin to migrate into the WM, differentiate into oligodendrocytes, and initiate myelination of the axons. This is maximal at about the end of the first postnatal week (Reynolds and Wilkin, 1988) and coincides with the peak of astrocyte death we observed at about P7 (Fig. 2). It is possible that astrocytes that are initially required to support the afferent and efferent axons in the developing WM are no longer needed once oligodendrocytes differentiate and begin to ensheathe the axons. Similarly, many of the astrocytes in the developing IGL may become superfluous once a sufficient density of neurons accumulates there.

In mechanistic terms, it is possible that astrocyte death is due to a lack of adequate survival factors, as is thought to be the case for normal neuronal and oligodendrocyte death. Cells of the oligodendrocyte lineage migrating into the developing WM (Reynolds and Wilkin, 1988), for example, may compete with astrocytes for survival factors, thereby resulting in the death of many of the astrocytes at the time the oligodendrocyte lineage cells arrive. Granule cell neurons accumulating in the developing IGL might contribute to astrocyte death in the IGL in the same way. If astrocyte death in the cerebellum reflects a lack of survival factors, then, once the putative survival factors have been identified, it should be possible to suppress the death by experimentally providing extra survival factors as has been done for neurons (Levi-Montalcini and Booker, 1960; Hofer and Barde, 1988; Oppenheim et al., 1988; Sendtner et al., 1992) and oligodendrocytes (Barres et al., 1992).

Whatever the purpose and mechanism of glial cell death, the recognition that large numbers of macroglial cells die during normal CNS development suggests that glial cell death, like neuronal cell death, is a fundamental feature of vertebrate neural development.

\section{References}

Altman J (1972a) Postnatal development of the cerebellar cortex in the rat. I. The external germinal layer and the transitional molecular layer. J Comp Neurol 145:353-398.

Altman J (1972b) Postnatal development of the cerebellar cortex in the rat. III. Maturation of the components of the granular layer. J Comp Neurol 145:465-514

Altman J, Nicholson JL (1971) Cell pyknosis in the cerebellar cortex of infant rats following low-level x-irradiation. Radiation Res 46: $476-489$.

Arends MJ, Morris RG, Wyllie AII (1990) Apoptosis: the role of endonuclease. Am J Pathol 136:593-608.

Ashwell K (1990) Microglia and cell death in the developing mouse cerebellum. Dev Brain Res 55:219-230.

Barde YA (1989) Trophic factors and neuronal survival. Neuron 2:1525-1524.

Barres BA, Hart IK, Coles HSR, Burne JF, Voyvodic JT, Richardson WD, Raff MC (1992) Cell death and control of cell survival in the oligodendrocyte lineage. Cell 70:31-46.

Barres BA, Jacobson MD, Schmid R, Sendtner M, Raff MC (1993) Does oligodendrocyte survival depend on axons? Curr Biol 3:489497.

Bertram JF, Nurcombe V (1992) Counting cells with the new stereology. Trends Cell Biol 2:177-180.

Bignami A, Eng LF; Dahl D, Uyeda CT (1972) Localization of the glial fibrillary acidic protein in astrocytes by immunofluorescence. Brain Res 43:429-435.

Bovolenta P, Liem RKH, Mason CA (1984) Development of cerebellar astroglia: transitions in form and cytoskeletal content. Dev Biol 102: 248-259.

Boyes BE, Kim SU, Lee V, Sung SC (1986) Immunohistochemical colocalization of $\mathrm{S}-100 \mathrm{~b}$ and the glial fibrillary acidic protein in rat brain. Neuroscience 17:857-865.

Bursch W, Paffe S, Putz B, Barthel G, Schulte-Hermann R (1990) Determination of the length of the histological stages in normal liver and in altered hepatic foci of rats. Carcinogenesis 11:817-853.

Clarke PGH (1990) Developmental cell death: morphological diversity and multiple mechanisms. Anat Embryol (Berl) 181:195-213. 
Coggeshall R (1992) A consideration of neural counting methods. Trends Neurosci 15:9-13.

Coggeshall RE, Pover CM, Kwiat GC, Fitzgerald M (1993) Erythrocyte nuclei resemble dying ncurons in cmbryonic dorsal root ganglia. Neurosci Lett 157:41-44.

Cowan WM, Fawcett JW, O'Leary DDM, Stanfield BB (1984) Regressive events in neurogenesis. Science 225:1258-1265.

Cruz-Orive LM, Weibel ER (1990) Recent stereological methods for cell biology: a brief survey. Am J Physiol 258:L148-L156.

Ellis RE, Yuan J, Horvitz HR (1991) Mechanisms and functions of cell death. Annu Rev Cell Biol 7:663-698.

Friedman B, Hockfield S, Black JA, Woodruff KA, Waxman SG (1989) In situ demonstration of mature oligodendrocytes and their processes: an immunocytochemical study with a new monoclonal antibody, RIP. Glia 2:380-390.

Gavrieli Y, Sherman Y, Ben-Sasson SA (1992) Identification of programmed cell death in situ via specific labeling of nuclear DNA fragmentation. J Cell Biol 119:493-501.

Glucksmann A (1951) Cell deaths in normal vertebrate ontogeny. Biol Rev 26:59-86.

Goldman JE, Hirano M, Yu RK, Seyfried TN (1984) GD3 ganglioside is a glycolipid characteristic of immature neuroectodermal cells. J Neuroimmunol 7:179-192.

Gorczyca W, Gong J, Darzynkiewicz. Z (1993) Detection of DNA strand breaks in individual apoptotic cells by the in situ terminal deoxynucleotidyl transferase and nick translation assays. Cancer Res 53:1945-1951

Gould E, Woolley CS, McEwen BS (1991) Naturally occurring cell death in the developing dentate gyrus of the rat. J Comp Neurol 304 $408-418$.

Hildebrand C (1971) Ultrastructural and light-microscopic studies of the developing feline spinal cord white matter. II. Cell death and myelin sheath disintegration in the early postnatal period. Acta Physiol Scand [Suppl] 364:109-144.

Hofer MM, Barde YA (1988) Brain-derived neurotrophic factor prevents neuronal death in vivo. Nature 331:261-262.

Hume DA. Perry VH, Gordon S (1983) Immunochemical localization of a macrophage-specific antigen in developing mouse retina: phagocytosis of dying neurons and differentiation of microglial cells to form a regular array in the plexiform layers. J Cell Biol 7:253-257.

Jacobson M (1991) Developmental biology, 3d ed, pp 311-321. New York: Plenum.

Janowsky JS, Finlay BL (1983) Cell degeneration in early developnent of the forebrain and cerebellum. Anat Embryol (Berl) 167:439-447.

Johnson EM Jr, Deckwerth TL (1993) Molecular mechanisms of developmental neuronal death. Annu Rev Neurosci 16:31-46.

Knapp PE, Skoff RP, Redstone DW (1986) Oligodendroglial cell death in jimpy mice: an explanation for the myelin deficit. J Neurosci 6:2813-2822.

Koppel H, Lewis PD, Patel AJ (1983) Cell death in the external granular layer of normal and undernourished rats: further observations, including estimates of rate of cell loss. Cell Tissue Kinet 16:99-106.

Korr H (1989) Proliferation of different cell types in the brain. Adv Anat Embryol Cell Biol 61:1-69.

Landry CF, Ivy GO, Brown IR (1990) Developmental expression of glial fibrillary acidic protein mRNA in the rat brain analyzed by in situ hybridization. J Neurosci Res 25:194-203.

Larsell O (1952) The morphogenesis and adult pattern of the lobules and fissures of the cerebellum of the white rat. J Comp Neurol 97: 281-356.

Levi-Montalcini R, Booker B (1960) Excessive growth of the sympathetic ganglia evoked by a protein isolated from mouse salivary glands. Proc Natl Acad Sci USA 46:373-384.

Lewis PD (1975) Cell death in the germinal layers of the postnatal rat brain. Neuropathol Appl Neurobiol 1:21-29.

Miale IL, Sidman RL (1961) An autoradiographic analysis of histogenesis in the mouse cerebellum. Exp Neurol 4:277-296.

Oppenheim RW (1981) Neuronal cell death and some related regressive phenomena during neurogenesis: a selective historical review and progress report. In: Studies in developmental neurobiology. Essays in honor of Viktor Hamburger (Cowan WM, ed), pp 74-133. New York: Oxford UP.

Oppenheim RW (1991) Cell death during development of the nervous system. Annu Rev Neurosci 14:453-501

Oppenheim RW, Haverkamp LJ, Prevette D, McManaman JL, Appel SH (1988) Reduction of naturally occurring motoneuronal death in vivo by a target-derived neurotrophic factor. Science 240:919-922.

Perry VH, Henderson Z, Linden R (1983) Postnatal changes in retinal ganglion cell and optic nerve axon populations in the pigmented rat. J Comp Neurol 219:356-368.

Purves D (1988) Body and mind. Cambridge, MA: Harvard UP.

Reynolds R, Wilkin GP (1988) Development of macroglial cells in rat cerebellum. II. An in situ immunohistochemical study of oligodendroglial lineage from precursor to mature myelinating cell. Development 102:409-425.

Reynolds R, Wilkin GP (1991) Oligodendroglial progenitor cells but not oligodendroglia divide during normal development of the rat cerebellum. J Neurocytol 20:216-224.

Sendtner M, Schmalbruch H, Stöckli KA, Carroll P, Kreutzberg GW, Thoenen H (1992) Ciliary neurotrophic factor prevents degeneration of motor neurons in mouse mutant progressive motor neuronopathy. Nature 358:502-504.

Skoff RP, Knapp PE (1991) Division of astroblasts and oligodendrob lasts in postnatal rodent brain: evidence for separate astrocyte and oligodendrocyte lineages. Glia 4:165-174.

Sinleyne RJ, Goldowite D (1989) Development and death of external granular layer cells in the weaver mouse cerebellum: a quantitative study. J Neurosci 9:1608-1620.

Soriano E, del Rio JA, Auladell C (1993) Characterization of the phenotype and birthdates of pyknotic dead cells in the nervous system by a combination of DNA staining and immunohistochemistry for 5 '-bromodeoxyuridine and neural antigens. J Histochem Cytochem $41: 819-827$

Sturrock RR (1976) Development of the mouse anterior commissure. III. Changes in total number of astroglia, mitotic cells and dead cells in the anterior and posterior limbs with age. Zbl Vet Med $\mathrm{C}$ Anat Hist Embryol 5:244-252.

Wijsman JH, Jonker RR, Keijzer R, van de Velde CJH, Cornelisse CJ, van Dierendonck JH (1993) A new method to detect apoptosis in paraffin sections: in situ end-labeling of fragmented DNA. J Histochem Cytochem 41:7-12.

Wood KA, Dipasquale B, Youle RJ (1993) In situ labeling of granule cells for apoptosis-associated DNA fragnentation reveals different mechanisms of cell loss in developing cerebellum. Neuron 11:621632.

Wyllie AH, Kerr JFR, Currie AR (1980) Cell death: the significance of apoptosis. Int Rev Cytol 68:251-307. 